\title{
LITERATURA FANTÁSTICA NO BRASIL
}

\section{Hélio Lopes}

O renovado interesse pelas narrativas fantásticas levou-nos a pensar no Brasil do século XIX, quando aqui se implantava o movimento romântico. Não é de admirar a íntima relação entre Romantismo e Fantástico. A abertura total aos caminhos da imaginação que os românticos apregoaram deu passagem a esta forma narrativa. A ela não fugiram os mais respeitáveis nomes daquelas nações cuja influência notória em nosso principiante nacionalismo literário não se desconhece: Inglaterra, França e Alemanha.

Mesmo com o risco dos retrospectos históricos neste momento de mais conspícuas abordagens críticas, faz-se necessário olhar um pouco para trás e perguntarmos se no terreno do fantástico se produziu alguma coisa nestas letras teimosas em não abandonar as placentas européias .

Vamos ocupar-nos de duas presenças alemãs no início do século XIX, modestas e ignoradas, mas significativas quando pensamos na influência dos escritores alemães neste gênero. $O$ nome de Hoffmann obrigatoriamente é lembrado quando se fala em fantástico. A presença de Hoffmann, no entanto, na Literatura Brasileira exige estudo à parte: minuciosa pesquisa desde o alvorecer de nosso Romantismo. Possivelmente a primeira obra de Hoffmann a publicar-se no Brasil terá sido "O Morgado", na "Biblioteca brasílica" da revista Minerva Brasiliense (1843-1845), mas é bem plausível que antes destes anos um ou outro de seus contos tenha surgido em nossa imprensa periódica. De qualquer forma, deixamo-lo por ora à margem de nosso interesse como também outros nomes relevantes como o de Goethe, por exemplo, com o Fausto. E, dentro de nossas letras, também não nos ocupamos de Álvares de Azevedo com a sua Noite na taverna e Macário, por demais conhecidas. Vamos ater-nos a gente mais modesta, mas que está na fonte mesma desta espécie de narração a que os nossos letrados se opunham quando, com certeza, especificavam esta face do Romantismo de frenético e gótico. 
O desconhecimento ou a animadversão a certos livros e autores considerados menores constrange-se reconhecer-lhes um valor que mui prazerosamente gostaríamos de continuar negando. E antes de chegarmos aos textos alemães de nosso atual interesse, apenas a título de curiosidade gostariamos de lembrar duas obras de nossas letras, como exemp!o, pertencentes à decada de 60 . Uma é o romance Paulo, de Bruno Seabra (1837-1876), publicado em 1861 e outro é $A$ luneta mágica, de Joaquim Manuel de Macedo (1820-1887), cuja primeira edição é de 1869 Estes dois livros são tirados do segundo momento de nosso Romantismo, quando o Fantástico já estava aceito e caminharia mesmo, contrariando as leis fáceis das assim chamadas "escolas", para dentro do "realismo" num violento desmentido às rígidas imposições didáticas.

Pode parecer incômodo, mas não há como fugir da estereotipada figura do Dr. Macedinho conhecido por todo o mundo escolar como autor de ingênuos romances cheios de moreninhas e moços loiros. $A$ luneta mágica revela-nos um Macedo diferente, irônico, bom conhecedor da magia, quando faz o armênio produzir as duas lunetas. A descrição do ambiente onde se opera a magia é minuciosa e valeria a pena submetê-la à análise para se ver até quanto Macedo se prende nos detalhes apontados pelas doutrinas esotéricas.

A história do pobre Simplício é uma divertida crítica à humanidade e as minuciosas anotações da realidade social - familiar, urbana, nacional —são facilmente aceitas dentro das leis da verossimilhança. Este mundo tranqüilo, esta ordem rotineira, estabelecida, é quebrada com violência pela presença misteriosa de um homem dotado de poderes extraordinários. É o armênio, sem outra identificação qualquer senão a da origem fascinante de sua terra longínqua, perdido no anonimato da capital do Império. Os transtornos que este armênio causa para satisfazer à miopia de Simplício são interrompidos com humor. O trágico dos excessos - as extremas visões do bem e do mal - levam Simplício à margem da loucura e do suicídio. Quando o infeliz vai precipitar-se para a morte do alto do Corcovado,

"(...) duas mãos possantes suspenderam-me pelas orelhas, pelas orelhas me contiveram por momentos entie a vida e a morte, e, sempre pelas orelhas, me tiraram da boca do abismo, e me depuseram no chão.

- Ainda é cedo, criança! disse a voz rouca do homem que me salvara, puxando-me as orelhas.

Reconheci o homem pela voz.

Era o armênio"

(1). - Macedo, Joaquim Manuel de - A luneta mágica, (São Paulo, Saraiva, 1961), (Col. Saraiva, 1951), p. 214-215. 
Se fosse necessário, não seria difícil encaixar o nome do autor desta história dentro de uma tradição européia que o engrandecesse. $\mathrm{O}$ aspecto moralizante pequeno-burguês de Macedo aqui presente não o desonra nessa vertente romântica. Dentro do comedimento de homens sensato, bem comportado, como era Hoffman, o recurso à magia não ultrapassa o pretexto fácil, mas bastante funcional, para conseguir o fim pedagógico em vista: uma lição de vida. Mesmo entre os mais ortodoxos cultores do fantástico este recurso não deixou de ser usado. A história, muitas vezes, se transforma numa fábula moralizante. E com isso perde a força do extraordinário.

E preciso, ainda, colocar $A$ luneta mágica entre algumas outras obras do romancista. Nestas se encontram recorrências a crendices populares, ao clima de mistério tão próprio do Romantismo e tão expressivo como recurso às potências irracionais do homem e a seu possível dom de participar de forças extraterrenas. De qualquer forma, até que limites nos poderia levar Macedo com esta curiosa sugestão de estudo?

Também o romance Paulo, de Bruno Seabra, nome lembrado mais como poeta menor de aspecto campesino, está preso aos moldes da narrativa romântica: o moço pobre à procura de melhor sorte para se casar com a noiva rica. Os ingredientes na composição da trama são os de sempre. Mas, de súbito ocorre o inesperado, aquilo que a sã filosofia nega naturalmente ao homem, a "actio in distans" $\mathrm{E}$ acontece o maravilhoso trágico.

Paulo, jovem pintor, pernambucano, está no Rio. Espera com sua arte adquirir dinheiro suficiente para se poder casar com a filha de um comendador. Paulo tem um amigo, Eugênio, escritor, para quem o mundo "era a sua consciência, o seu conselheiro a circunstância, o seu rei Paulo de Kock, e a sua pátria a cabeça de "Sócrates", um cão por quem se desvelava extremosamente" (2).

Um dia, Paulo recebe de sua irmã a carta fatídica: Emília, a noiva por quem Paulo se sacrificava, iria casar-se com outro no dia em que aniversariava. Ora, Paulo havia pintado, ainda em Pernambuco, o retrato de Emília, e o trouxera consigo "como um talismã precioso" (3). No dia do casamento de Emília, Paulo está sózinho em casa, completamente transtornado. Rasga furiosamente a carta, dá um tiro no retrato de Emília. "Um momento, e o eco do tiro repercutiu por

(2). - Seabra, Bruno - Paulo, (São Paulo), Editora Três, (1973), (Obras imortais de nossa literatura, 25), p. 68.

(3). - Id., ibid., p. 114. 
todo o quarto, seguido do estrondo de um corpo que caíra! Acabava de dar meia-noite!" (4).

Quando, de madrugada, Paulo retorna a si, Eugênio diz-lhe onde se encontra: "Estás no teu quarto" Paulo, "desfigurado como um cadáver", diz a Eugênio:

"- Sabes (. .), quando ela morreu eu senti suas mãos frias apertarem as minhas, e ouvi dizer-me nos ouvidos: adeus para sempre" (5).

Com o pouco dinheiro em reserva, Paulo manda Eugênio comprar três passagens para o Norte: o cão "Sócrates" vai com eles. Doente, em casa de sua mãe, Paulo recebe a visita do comendador. Está de luto. Conta-lhe o pai da ex-noiva a festa do casamento da filha e como ela morreu em seus braços, ao bater o relógio a meia-noite.

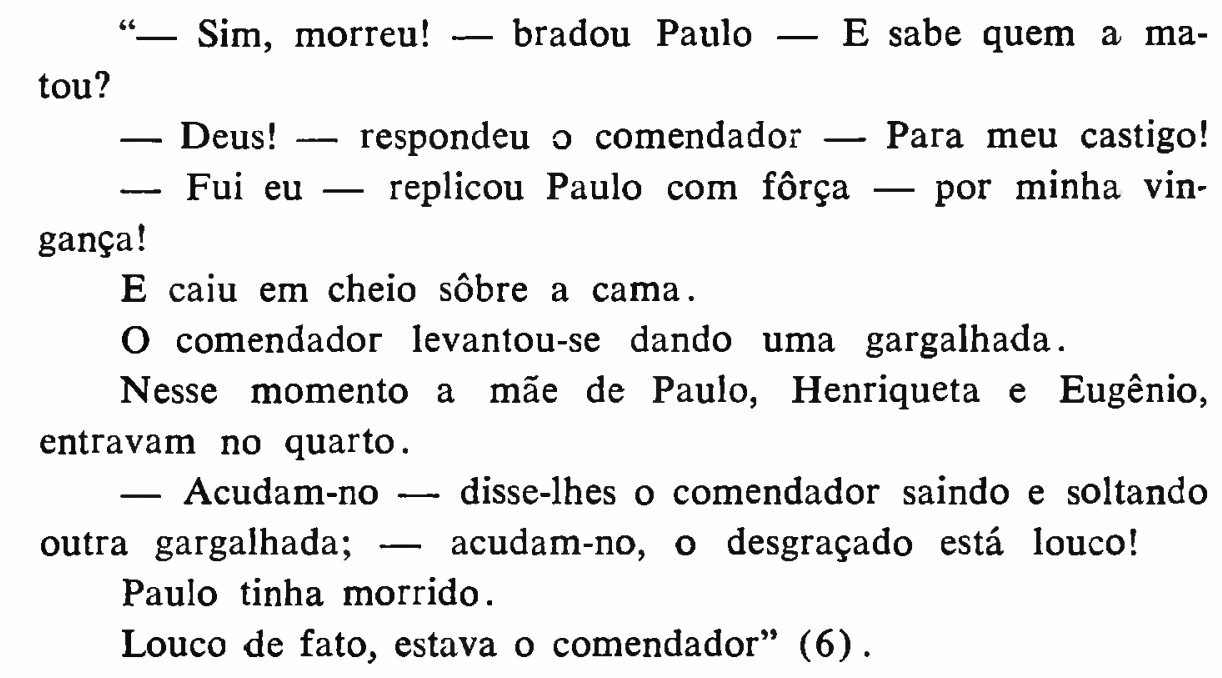

Poder-se-ia incriminar o romance de Bruno Seabra como esteticamente mal realizado. Não é, na verdade, obra que se imponha a uma apaixonante leitura nem vale desculpar o escritor pelos seus pouros anos, quando a produziu. Será talvez até possível ver nos defeitos de uma obra da mocidade as virtudes que a marcam. E o elemento fantástico aí está e não é possível esquecê-lo, ou deixá-lo à margem quando se fizer o estudo organizado desta faceta desconhecida ou mal ronhecida de nosso Romantismo. Não lemos as outras obras de ficção deste amável poeta ruralista. O clima tenebroso, irracional, desdenhoso da sociedade preocupada apenas com o dinheiro em oposição ao artista na miséria e na luta pelo ideal é o clima constante de grande
(4). - Id., ibid., p. 118.
(5). - Id., ibid., p. 124.
(6). - Id., ibid., p. 132 . 
número de obras românticas. Sobretudo a oposição artista e sociedade. Ela nem sempre correspondeu, no século passado, a uma verdade social. O Macedo é um exemplo. Bernardo Guimarães é outro. O próprio Bruno Seabra também parece não ter tido motivos de maiores queixas. Sua poesia, por exemplo, é alegre, sadia. $O$ aspecto, portanto, verificável em Paulo, deverá provir de outras influências aincia por assinalar.

Destes dois citados exemplos o de Bruno Seabra aproxima-se em alguns pontos da versão de um conto fantástico alemão estampado em o número 8 do jornal $O$ Beija-flor que tem como sub-título Anais brasileiros de Ciência, Política, Literatura etc., publicado por uma sociedade de literatos no Rio de Janeiro, tipografia de Gueffier e Cia, em 1830. A Biblioteca Nacional possui deste jornal oito números (7).

Infelizmente não se identifica nem o nome do autor nem do tradutor desta assim chamada novela com plausíveis razões traduzida do francês. O que interessa assinalar de início é a data da publicação. Pierre-Georges Castex em Le conte fantastique en France de Nodier à Maupassant estabelece os anos próximos de $1830 \mathrm{com}$ os da idade de ouro do conto fantástico na França (8). Neste mesmo período aqui, no Brasil, começam a surgir traduções e imitações desses contos ou romances. Sérá possível estabelecermos uma coincidência de datas? Parece-me que sim. Parece-me que a década de 30, se ulteriores descobertas não nos desmentirem, marca o início deste tipo de narração no Brasil. Pelo menos Justiniano José da Rocha, o introdutor do folhetim em nossa imprensa periódica, faz ou incita a fazer traduções e imitações desses contos e romances e dá o exemplo em 1836 com a imitação de La peau de chagrin, de Balzac, de 1831 .

Em o número 6 de 20 de junho de 1836 de $O$ Cronista manifesta a intenção de trazer aos leitores de seu jornal "as belezas da moderna literatura" e começa exatamente com a imitação do romance de Balzac:

“( ) Este conto fantástico de que hoje publicamos parte foi filho daquela resolução. Imitada da novela terrível de Balzac La peau de chagrin (,) possa A luva misteriosa agradar aos leitores brasileiros como La peau de chagrin agradou aos franceses"

(7). - Viana, Hélio - Contribuição à história da imprensa brasileira (1812-1869), Rio de Janeiro, Imprensa Nacional, 1945, (Ministério da Educação e Saúde, INL, Col. B 1, N), p. 114-119. Também José Aderaldo Castello faz referência a esta presença em "Os pródromos do Romantismo" In: Coutinho, Afrânio, dir. A Literatura no Brasil, $2^{\circ}$ ed., Rio de Janeiro, Ed. Sul Americana, 1969, v. 2, p. 51.

(8) - Castex, Pierre - Georges - Le conte fantastique en France de Nodier à Maupassant, Paris, José Corti, (1971), p. 57-80. 
A promessa de Justiniano José da Rocha foi largamente cumprida. Mas $O$ Beija-flor já o havia precedido de seis anos com a novela "Hermíone", alemã, que se diz do século XIV e se resume no seguinte: o barão de Arnhein hospeda um estranho personagem persa. Em paga da proteção e hospedagem que lhe dá, impõe a condição de ser por ele iniciado nos mistérios da magia. Um dia, ao abandonar a casa do barão, promete-lhe o persa enviar sua filha Hermíone. Ela continuará com as instruções sobre a magia. Uma condição, porém, lhe é imposta: não se deixar dominar pela rara beleza da moça. Chega Hermíone. O barão apaixona-se por ela e casam-se. Embora desconfie das atitudes estranhas da esposa, vivem felizes até o dia do batizado do filho, fruto deste casamento. Hermíone é acusada de feiticeira. O barão quer provar o contrário e asperge com água-benta o talismã que Hermíone trazia sempre sobre a testa. Hermíone desmaia, é acudida e levada ao quarto. O barão tranca-o por fora e volta à igreja. Quando reabrem a porta do aposento, no lugar onde repousava Hermíone há apenas uma punhado de cinzas. Três anos depois morre o barão sem deixar descendentes e com ele acaba sua família.

Estranha nesta novela alemã o nome grego da mulher, filha de um persa. Será este o verdadeiro título da novela? E como deve pertencer às centenas dessas produções proliferantes de contos fantásticos na Alemanha em fins do século XVIII e princípios do século XIX não alimentamos grande esperança de se vir a identificar o autor de "Hermíone" Os recursos aproveitados são os comuns: o prestígio do Oriente: um persa (no romance de Macedo, um armênio); a presença de um talismã cuja destruição ocasiona a morte da mulher amada (como no romance de Bruno Seabra). O escritor brasileiro não recorre à magia, a pactos diabólicos, a ciências ocultas. A narração das desditas de Paulo mantém-se dentro da linha do real (não "realista") plausível e o fato de um assassínio à distância deveria ser aceito pelos conhecimentos que a parapsicologia então punha em voga embora se atribuissem os fenômenos a poderes extra-terrenos.

Bruno Seabra não explica nada. Assim deixa o mistério entregue ao leitor e essa entrega do fato misterioso estabelece o clima do fantástico.

A novela alemã está perfeitamente incluída no fantástico primeiro do século XIX, o romance brasileiro no segundo momento, quando começaram a substituir o recurso ao esotérico pelo recurso ao científico. Naquela há, por conseguinte, o recuo no tempo: a ação colocase no século XIV Quem se daria ao trabalho de verificar a sua veracidade? $\mathrm{O}$ fato é simplesmente aceito dentro do maravilhoso terrível, quando o poder mágico (parece que diabólico), é destruído por um sacramental (a água-benta), opondo, portanto, dois princípios - 
o do bem e do mal, com a conseqüente derrota deste. No romance Paulo a contemporaneidade não destrói o efeito da verosssimilhança. fato estranho é aceito no mundo ficcional estabelecido. Em ambos a morte, e a loucura num, organizam o clima de terror pela transgressão da ordem.

Com as palavras do apresentador do romance de Bruno Seabra, um enigmático $\mathbf{J}$., passaremos a outra narrativa fantástica alemã, da nossa década de 30 :

"Paulo é um conto que tu lerás como aquelas histórias fantásticas de Hoffmann ou de Buerger; o coração palpita com medo do desenlace e sente-se de cada palavra, de cada idéia resultar uma coisa sob:enatural que não pode acontecer, mas que no entretanto nos enche de terror como se ela tivesse lugar junto a nós; Paulo interessa pelo drama, pelas personagens e, ainda mais por alguma coisa de brasileiro que se descobre resse encanto do maravilhoso alemão" (9)

O autor destaca ao lado de Hoffman o nome de Buerger, menos divulgado, mas que teve, no seu momento histórico. importância e ampla admiração.

Gottfried August Buerger (1747-1794), representante do Sturm und Drang, é o autor de duas célebres baladas: "Lenore" e "Der wilde Jaeger", ambas traduzidas para o português por Alexandre Herculano. A primeira foi publicada em 1834 no Repositório literário, Porto, v. 1, n. ${ }^{\circ} 3$ e a segunda no Panorama, 1839, v.3, n. ${ }^{\circ} 96$ e ambas as traduções estão incluidas em seu volume de Poesias (10). Das duas baladas se pode ler apreciável crítica erudita em Pedro de Almeida Moura - A balada alemã à luz da psicologia - (11)

Da balada "O caçador feroz" (Der wilde Jaeger) tirou Gonçalves Dias a epígrafe para a parte III de seu poema "O soldado espanhol", infelizmente não datado, constante em seus Primeiros cantos $\left(1 .^{\circ}\right.$ ed. 1846). O poema de Gonçalves Dias tem o clima das baladas e repete a velha história da espôsa infiel: o marido parte para a guerra:

(9). - Seabra, Bruno - op. cit., p. 29.

(10) - Carreira, Gabriela - A literatura alemã em traduções portuguesas, ensaio bibliográfico, Lisboa, Instituto de Cultura alemã, 1944.

(11) . - Moura, Pedro de Almeida - A balada alemã à luz da psicologia, São Paulo, Univ. de São Paulo, FFCL, Bol. 202, Cad., de Língua e Literatura alemã ( 1,1955, p. 77-104. 


\begin{abstract}
"Como o Cid, oh crua sorte!
Não me vou nesta campanha

Guerrear contia o crescente,

Porém sim contra os d'Espanha!

Não me aterram; porém sinto

Cerrar-se o meu coração,

Sinto deixar-te, meu anjo,

Meu prazer, minha afeição"
\end{abstract}

Não havendo mais notícias dele, a mulher enamora-se do "soberbo infanção", que aparece na parte 3 do poema. O desfecho é o comum reaparece o esposo e apunhala os amantes. A noite do festim e da morte é de inverno: "Era noite hibernal" e a natureza, fora, contrasta com a alegria e calor da sala em festa, logo cenário da morte:
"A escuridão, a tempestade, e o vento,
Rugindo solto, indômito e terrível
Entre o negro do céu e o horror da terra,
Horrenda simpatia alimentavam"

Os dois pequenos versos epigrafando a parte 3 resumem, praticamente, a primeira estrofe de Buerger: "O conde deu sinal de partida: - $\overline{\mathbf{A}}$ caça! meus amigos" Longe de serem um mero enfeite, constituem exato resumo do espírito da balada alemã, transpondo para o atrevido conquistador a coragem e a audácia — também castigada — de " $\mathrm{O}$ caçador feroz" Grande admirador de Alexandre Herculano, é natural não desconhecesse a versão portuguesa da célebre balada. Não lhe aproveitou, porém, os versos. Nem, sequer, ajuntou ao nome de Buerger o nome do poema. Era suficiente o poeta. A balada era por demais conhecida e a simples leitura dos versos iniciais evocava todo o seu clima de trágico desfecho. Quando não, a música de Carl Maria von Weber, trouxera de novo à memória o nome de Buerger: A balada "Der wild Jaeger" servira de base para a ópera "Der Freischuetz", estreada em Berlim no ano de 1821.

O grande renome, porém, de Buerger se deve sobretudo a "Lenore", traduzida em todas as línguas e considerada obra tão perfeita que o próprio Goethe, dizem, gostava de a declamar com ênfase, impressionando a quantos o ouviam.

João Cardoso de Menezes e Souza (1827-1915), mais conhecido como barão de Paranapiacaba, arroga-se (erroneamente, ver-se-á em nota) a glória da prioridade na divulgação de Buerger:

"Estão em moda as baladas. Fui buscar na velha Alemanha a matéria da que te envio. Foi ali que mais viçou essa flor li- 
terária, plantada na idade-média. Essa balada é "Leonor" (Leonora), a mais célebre das que brotaram da fértil imaginação de Buerger Não há homem de letras que a conheça.

Em minha primeira mocidade, meu velho e bom amigo conselhei:o A. J. Ribas (12), hoje falecido, jurisconsulto e poeta, que o leu no original, para ele familiar, fez-me a narrativa daquela composição.

Sobre esse canevas tracei o bordado grosseiro da peça que vais ler.

Só muitos anos depois é que apareceu a versão de "Leonora", por A. Herculano (13) .

O que escrevi não é tradução nem pa:ódia. Aproveitei somente o pensamento de Buerger, desenvolvendo o tema a meu modo e livremente.

Não me vão emprestar a estulta pretensão de querer emparelhar com o mestre alemão.

Levei só em mina vulgarizar o assunto agora, que principia a ressuscitar o gosto por este gênero de literatura (14).

A falta de um modesto conhecimento da evolução dos fatos literários leva Cardoso de Menezes a uns pequenos erros na visão diacrônica da Literatura, mas é preciso reconhecer-lhe grande fidelidade ao modelo, embora o siga ou imite, diríamos de oitiva, e consegue êxito satisfatório em sua versificada narrativa, principalmente variando o ritmo e a estrofação: separa com clareza as diversas partes da ação e evita a monotonia. Além destas virtudes caseiras nada mais podemos

(12). - Trata-se de Antonio Joaquim Ribas, nascido no Rio de Janeiro em 1820. Cfr. Sacramento Blake - Dicionário bibliográfico brasileiro, v. 1, p. 203-205.

(13). - Cardoso de Menezes ignorava que a tradução de A. Herculano saíra primeiro em jornal (1834). O futuro poeta brasileiro contava apenas sete anos de idade. Só conheceu a versão de Herculano quando estampada no vol. de Poesias constituído de três partes ("Harpa do crente", "Poesias várias" e "Versões), cuja $1^{\circ}$ ed. é de 1850. Desconhecia também a divulgação de "Lenore" feita por Justiniano José da Rocha, em 1836. Quer em Portugal, quer no Brasil já se conhecia Buerger antes de Cardoso de Menezes.

(14). - Souza, João Cardoso de Menezes e (Ba-ão de Paranapiacaba) Poesias e prosas seletas, Rio de Janeiro, Leuzinger, 1910, p. 77.

O poema vai da p. 78 à p. 87 e é precedido do folhetim de Deiró (Pedro Eunápio da Silva Deiró) conforme Sacramento Blake publicado no Jornal do Comércio, do Rio de Janeiro, em agosto de 1897 com o mesmo título com que vem no livro "Leonor ou o castigo da blasfêmia"

"Leonor", portanto, é posterio- à ed. de Harpa gemedora, São Paulo, Tip. Silva Sobral, 1847, onde aparece um romance "Otávio e Branca ou A maldição materna", p. 99-115, também de origem européia. Aos seus versos Cardoso de Menezes ajunta uma nota sôbre vampiros, p. 116. 
exigir do poeta. Ele se comporta dentro dos padrões da linguagem do tempo.

Outra tradução de "Lenore" aparece em 1874 nas Poesias alemãs, de Bernardo Taveira Junior, vertidas do original, publicadas em Porto Alegre (15). Nós a conhecemos por intermédio de Geir Campos que a transcreve em Poesia alemã traduzida no Brasil, em edição bilíngüe (16).

Como observa Wolfang Kayser, é motivo freqüente das baladas pré-românticas o aparecimento das pessoas amadas mortas ao companheiro sobrevivente, assim como aparece na poesia inglesa e alemã de que é exemplo a "Lenore" de Buerger (17). Esta célebre balada conta a história de uma noiva (Leonor) desesperada porque, festejando todos o regresso dos soldados depois da batalha de Praga, o noivo (Gu.lherme) não aparece e dele não se tem notícia nenhuma. Morreu? Esqueceu-a? Trocou-a por outra? Leonor não aceita os conselhos da mãe, que procura apaziguar-lhe o espírito, e blasfema contra Deus. Uma noite Leonor ouve alguém chamá-la. O relógio batera onze horas. Reconhece a voz e o cavalheiro: é Guilherme. Quer retê-lo em casa. Ele a incita a acompanhá-la ao leito de noivado. Leonor pula à garupa do cavalo. O leito de núpcias está a cem milhas de distância. O cavalo dispara pelos campos, atravessam cidades e vilas e são acompanhados por uma sarabanda infernal. Ao apagar das estrêlas chegam à porta de um cemitério. As armaduras do cavaleiro desaparecem - é um esqueleto. Abre-se a terra e o corcel some no ab.smo. O espaço está cheio de uivos e lamentos sobem da terra. Leonor encontra o seu "noivado no sepulcro", ouvindo dos fantasmas esta lição: não se deve ir contra o céu. Estás livre de teu corpo e Deus seja misericordioso com tua alma.

"Mit Gott im Himmel hadre nicht!

Des Leibes bist du ledig;

Gott sei der See'e gnädig!"

São estes versos finais. A composição é de trinta e oito oitavas e a distribuição rímica obedece à seguinte forma: ababccdd. Ȧs vezes a mesma palavra, na mesma estrofe, como na sétima "Sakrament", rima consigo mesma: "Das hochgelobte Sakrament" (v . 51), "Das lindert

(15) - Taveira Junior, Bernardo - Poesias alemās, vertidas para o original, intr. Carlos Koseritz, Po to Alegre, 1875.

(16). - Campos, Geir - Poesia alemã traduzida no Brasil, Rio de Janeiro, Serviço de Doc. do MEC, 1960, p. 52-69.

(17) - Keyser, Wolfgang - Análise e interpretação da obra literária, $3^{\circ}$ ed., trad. Pau'o Quintela, Coimbra, Armênio Amado, 1963, v. 1, p. 88. 
mir kein Sakrament" (v. 59). Outras vezes a iteração é total como na estrofe 11:

\author{
"O Mutter, was ist Seligkeit? \\ O Mutter, was ist Hölle? \\ Bei ihm, bei ihm ist Seligkeit, \\ Und ohne Wilhelm Hölle!"
}

Repetições assim de versos, integrais ou parciais, criam um clima de alta dramaticidade. Outras funcionam à maneira de ritornelo em ambíguas conotações. Sobretudo agradou-me este verso 34 da estrofe 17: "Wir und die Toten reiten schnell (Nós e os mortos cavalgamos depressa)" É a resposta do cavaleiro a Leonor admirada de terem de vencer cem milhas até o leito de noivado em tão pouco espaço de tempo. A separação entre o "Wir" (nós) e o "die Toten" (os mortos), estabelece uma dúvida admirável. $O$ cavalheiro sabe o que fala, mas Leonor não o entende. A dúvida não lhe chega ao coração. Nem mesmo o leitor a entende com perfeição, pois ignora ser o fantasm? de Guilherme aquele estranho cavaleiro. Na estrofe 20 , verso 58 , volta o mesmo verso precedido de um grito de triunfo: "Hurra! Die Toten reiten schnell!" A exclamação justifica-se porque o corcel voa sobre os campos e a ponte por onde atravessa "troveja" (dornner). No sentido de retumbar, aproveitado por Taveira Junior, falta incluir a conotação de tempestade e borrasca que esta em "dornner", muito mais forte e presago que o simples "retumbar" Depois, o mesmo verso ocorre quatro estrofes após, estrofe 24 , verso 190 e no verso 214 da estrofe 27 quando nesta última tudo ao redor parece voar: tudo quanto a lua ilumina, as distâncias, o mesmo céu, as mesmas estrêlas. Diante desta vertiginosa corrida, o grito feliz do cavaleiro: "Hurra, die Toten reiten schnell!", quando, afinal, chega ao destino ao sentir o bafejo do vento da manhã e ao ouvir o canto do galo anunciando o sol. São três versos de um exclamação triunfal fechados por um o último da estrofe - de declaração feliz de sossego:

\footnotetext{
"Vollb:acht, vollbracht ist unser Lauf!

Das Hochzeitsbette tut sich auf!

Die Toten reiten schnelle!

Wir sind, wir sind zur Stelle"
}

(Terminou, terminou nossa corrida!/ O leito nupcial se abre!/ Os mortos cavalgam depressa!/ Chegamos, chegamos ao lugar.) A riqueza expressiva dos versos alemães com seu ritmo violento e duro, com uma inimitável abundâncias de onomatopéias dificilmente pode ser transposta para a língua portuguesa. Onde estaria o poeta para recriar a 
atmosfera de terror e fantasmagoria desta cavalgada desabrida sob a clara luz do luar?

Madame de Staël não sabia deste poema nenhuma tradução satisfatória em francês. A única versão a que se refere com elogios é a de Spencer "o poeta inglês que melhor conhece o verdadeiro espírito dos idiomas estrangeiros" E devido à aproximação das duas línguas, alemão e inglês, é que se pode sentir toda a originalidade de estilo e versificação de Buerger Spencer, na opinião de Madame de Staël não apenas transpôs os elementos formais de alta expressividade, mas com eles as impressões apavorantes que o original consegue transferir ao leitor (18).

A tradução de Bernardo Taveira Junior é bastante fiel ao texto alemão. Esta tradução brasileira mantém o mesmo número de estrofes do original (32), em versos de redondilha maior, mas não conserva as rimas dos versos ímpares, transformando a oitava em duas estrofes de quatro versos nesta disposição: $-a-a-b-b$. A pontuação favorece ainda mais a linha divisória entre os versos. A única exceção está na última, onde os dois pontos depois de "ulular" nos remetem de imediato aos quatro versos finais. A louvável fidelidade ao original não destrói a fluidez de seus versos e da narrativa. Mas as grandes virtudes do texto original não se transferem ao texto em português. Essa falta não é para admirar quando se percebe a intenção do tradutor e a dificuldade de encontrar correspondentes em nossa língua para os efeitos sonoros e onomatopaicos do idioma alemão. As observações de Madame de Staël caberiam perfeitamente à tradução de Taveira Junior .

Louis Vax em $A$ arte e a literatura fantástica ensina que a poesia "não consiste, de modo algum, num conflito entre o real e o possível, mas numa transfiguração do real" por isso não é o gênero apropriado para o fantástico e diz, pouco adiante, do texto que nos ocupa:

"Na "Lenore" de Buerger, o soldado leva numa cavalgada louca a noiva para o túmulo, o seu leito nupcial. Não estamos diante de uma histó ia clássica de vampiros: o horror, inscrito desde princípio, mantém-se até o fim. Um ritmo brutal, um sopro selvagem ape tam as estrofes umas em cima das outras. O horror já só tem de realizar-se. Nada de especulações acerca da origem e da natureza dos vampiros; nenhuma esperança de lhe escapar. A poesia do ho*or não é o fantástico" (19).

(18). - Vax, Louis - $A$ arte $e$ a literatura fantástica, (tiad. João Costa), (Lisboa), Arcádia, (1972), (BAB, 146), p. 14.

(19). - M.me de Staël - De l'Allemagne, Paris, Garnier, (1932), v 1, p. 180 e seg. 
O que dizer então, a respeito da transcrição em prosa desta balada feita, presumimos com boas razōes, por Justiniano José da Rocha? Ela vem sem assinatura. Mas as palavras iniciais que a precedem, quando o jornalista introduz em seu jornal o folhetim, a princípio chamado de "folha literária", nos induzem a atribuir-lhe esta versão:

"Quase geralmente ignoradas são entre nós as letras alemães. Dos seus grandes poetas, dos seus Goethes, dos seus Szhiller nem as obras, nem o nome mesmo conhecemos. E (,) no entanto (,) é a literatura alemã uma das mais ricas, uma das poucas, senão a única que tem um tipo original e próprio, uma das que menos empréstimos pediu às letras gregas, e romanas. Julgamos acertar vulgarizando-a entre nós; algumas de nossas FOLHAS trarão versões dos seus melho es autores: sirva para hoje o seguinte conto: Lenore (20)"

Falta dizer o nome do autor e falta dizer que este "conto" é um poema já então largamente divulgado fora da Alemanha. Poderia ocorrer-nos a dúvida de que Justiniano lançasse mão de um texto anterior ao de Buerger, quando sabemos ter o poeta se utilizado de uma história já corrente e popular? Se fala de "conto" e não de "balada" será porque se baseou em algum texto em prosa em francês ou inglês? Acreditamos que não. Terá sido apenas uma liberdade que se deu. A verrsão, ou a transcrição em prosa, é muito fiel ao texto de Buerger e, como em nota se lê, diretamente traduzida do original. diz:

A primeira nota é muito curiosa. Refere-se à segunda estrofe que

"Der König und die Keiserin,

Des langen Haders müde,

Erweichten ihren harten Sinn

Und machten endlich Friede;

Und jedes Heer, mit Sing und Sang,

Mit Pauckenschlag und Kling und Klang,

Geschmuckt mit grünen Reisern,

Zog hein zu seinen Häusern"

E traduzida da seguinte forma: "Enfim cansados de suas ensangüentadas pendências o rei e a imperatriz aplacam as iras, e concluem a paz. E rã, tã, pã, - totó, totó, tó. (1) ao som do tambor e da correta cada exército, cada regimento, cada soldado coroado de verdealegres folhas retira-se para seus lares" A nota chama a atenção para

(20) - O cronista, $\mathrm{n}^{\circ} 9$, out, 1836. 
os seguintes: "Ou os tambores e cornetas da Alemanha não são como os nossos, ou por lá tocam de diferente maneira. Permitam nossos leitores que a "kling, klang" que vem no original, nos sirvamos desta expressão" O tradutor viu-se atrapalhado com o "Sing und Sang.

King und Klang" e descobriu a corneta no texto que fala apenas de toque de tímbalo. Taveira Junior traduz por "atabales vêm rufando" o "Mit Paukenschlag"

Outra prova da presença do texto original está na onomatopéia da estrofe 13: "Und aussen, horch! ging's trapp, trapp / Als wie von Rosses Hufen", versos 97-98, desprezada pela tradução em verso, mas presente na tradução em prosa: "Mas de fora que bulha se ouve? trap, trap, trap, é o andar de um cavalo" e a outra no verso 102 da mesma estrofe: "Ganz lose, leise, klinglingling" assim em português: "Escutemos, escutemos, dling, dling, dling! é o som da campainha" $\mathrm{Na}$ estrofe 19, quando começa o galopar do cavalo, traduz Justiniano: "A moça calça-se e salta na garupa e depois pacatá, pacatá, pacatá (1) é o retumbar do galope; ( .)" E a nota curiosa: "Cá na nossa terra é este o som do galope, e não hop, hop, hop, como vem no original" Depois, na estrofe ainda 26, Buerger usa da forma husch, husch, husch! imitando o som deslizante das folhas sêcas (Huschen quer dizer deslizar) a que compara a turbamulta de "birbantes" que segue o cavaleiro em disparada. Este som, não encontrado correspondente em português, Justiniano o conserva com pequena alteração: Hurch! hurch! hurch! todos voam atrás deles com a bulha do vento por entre folhas sêcas" A troca de sibilante pela vibrante foi desnecessária e menos feliz.

Estas anotações de ordem de linguagem demonstram em primeiro lugar como o autor tinha diante dos olhos o texto alemão e, em segundo lugar, uma certa preocupação crítica, talvez ingênua, mas não desprezível, pois revelam o desejo louvável de ser quanto possível fiel ao original.

Pergunta que agora se poderá fazer é suscitada pela observação de Louis Vax acima citada: o texto poético passado à prosa entrará na categoria do fantástico? A balada, ou melhor dizendo, o romance, do século XIX geralmente senão sempre, conta uma "história" É, afinal, uma narrativa e o "texto poético" vai diferenciar da "prosa" por elementos bastante secundários: o metro e rima. No caso de "Lenore", o leitor não informado sobre o texto de Buerger jamais pensará que esteja tendo uma "história" antes escrita em verso. Poderemos adotar as explicações de Todorov que, afinal, vêm a calhar com o pensamento de L. Vax, ao exigir para a existência do fantástico tanto a ausência do poético como do alegórico. 
A primeira condição para uma das formas do fantástico imposta por Todorov é a de o leitor "considerar o mundo das personagens como um mundo de pessoas vivas e hesitar entre uma explicação natural e uma explicação sobrenatural dos acontecimentos evocados" Esta alternativa existe. Somos colocados num mundo real: o imperador faz guerra, sabemos onde a batalha se travou, sabemos da volta dos soldados para casa, ouvimos o diálogo entre a mãe e a filha, tudo muito dentro das normas comuns.

Em seguida aparece um fantasma. Leonor não duvida que seja Guilherme: ouve-lhe a voz, monta em seu cavalo. Agora começa a segunda condição de Todorov: a hesitação do leitor é confiada "a uma personagem e ao mesmo tempo a hesitação se acha representada e se torna um dos temas da obra" Leonor não acredita estar sendo levada por um morto: "deixemos os mortos"; não acredita na possibilidade de vencer as cem milhas em tão curto espaço de tempo; e diante do que vê e sente no vertiginoso espaço da corrida é-lhe perguntado se está com medo. Na verdade não sabemos muito bem o que está acontecendo com Leonor: é uma alucinação dos seus sent:dos ou é uma realidade estranha? A "meia-noite" parece ser mesmo a hora dos fantasmas, mas a noite também é o espaço propício dos sonhos e dos pesadelos.

Finalmente, embora a narrativa contenha uma nítida lição moral, nós lhe podemos recusar "tanto a interpretação alegórica quanto a interpretação "poética" (21). Terminamos a leitura do conto, mas a solução da história ficou em suspenso. O mundo "real" de Leonor não tomou conhecimento do fato. Sua mãe, os moradores da cidade desapareceram da narrativa, consumando o desfecho da história. Como explicar o acontecimento? Estamos no terreno do fantástico.

A história de "Hermíone" bastante parecida com a de "O diabo apaixonado" de Cazotte, também analisada por Todorov, e a história de ". .Leonore" são dois exemplos do conto fantástico, de fonte alemã, em nosso Romantismo nascente. O motivo principal deste nosso estudo está em verificar a contribuição direta ou indireta, não importa, da literatura alemã na formação do Romantismo brasileiro. As contribuições inglesa e francesa são por demais declaradas, sab.das e repetidas. A alemã precisa de ser pesquisada e estudada. O veio é bastante rico e há muito ainda que desenterrar.

(21) - Todorov, Tzvetan - "A narrativa fantástica" In: As estruturas narrativas, São Paulo, Perspectiva, (1969), p. 147-166. 